\title{
Implementasi Good Governance dalam Pengelolaan Keuangan Desa di Desa Tempeh Kidul Kecamatan Tempeh Kabupaten Lumajang
}

\author{
Mimin Yatminiwati \\ Program Studi Akuntansi, STIE Widya Gama Lumajang \\ Email: miminyatminiwati02@gmail.com
}

https://doi.org/10.30741/wiga.v9i1.410

I N F O A R T I K E L

Tanggal masuk :

2 Februari 2019

Tanggal Revisi :

22 Maret 2019

Tanggal Diterima :

31 Maret 2019

\section{A B S T R A K}

Penelitian ini bertujuan mendeskripsikan tentang good governance pada pengelolaan Anggaran Pendapatan dan Belanja Desa (APBDes) di desa Tempeh Kidul kecamatan Tempeh kabupaten Lumajang. Objek penelitian ini adalah Implementasi good governance pada pengelolaan Anggaran Pendapatan dan Belanja Desa (APBDes) di desa Tempeh Kidul kecamatan Tempeh kabupaten Lumajang. Dalam penelitian ini, penulis menggunakan jenis penelitian kualitatif dengan pendekatan studi kasus. Teknik pengumpulan data yang digunakan adalah wawancara, observasi dokumentasi. Teknik analisis data yang digunakan adalah model analisis interaktif yang meliputi empat komponen, yaitu pengumpulan data, reduksi data, penyajian data, dan verifikasi. Hasil penelitian menunjukkan bahwa 1) Perencanaan APB Desa Tempeh Kidul dalam perencanaan pengelolaan keuangan desa cukup baik. 2) Pelaksanaan keuangan desa Tempeh Kidul secara keseluruhan terlaksana dengan baik. 3) Implementasi prinsip-prinsip good governance pada pengelolaan APB Desa Tempeh Kidul sudah dilaksanakan cukup baik oleh pemerintah desa.

Kata Kunci : Good Governance, Anggaran Pendapatan dan Belanja Desa

\begin{abstract}
A B S T R A C T
This study aims to describe Good Governance in the Management of Village Revenue and Expenditure Budget in Tempeh Kidul Village, Tempeh District, Lumajang Regency. The object of this research is the Implementation of Good Governance in the Management of Village Revenue and Expenditure Budget in Tempeh Kidul village, Tempeh sub-district, Lumajang district. In this study, the authors used a type of qualitative research with a case study approach. Data collection techniques used were interviews, documentation observation. The data analysis technique used is an interactive analysis model that includes four components, namely data collection, data reduction, data presentation, and verification. The results showed that 1) $A P B$ Planning in Tempeh Kidul Village in planning village financial management was quite good. 2) The overall implementation of the financial activities in the village of Tempeh Kidul is well implemented. 3) The implementation of the principles of Good Governance in the management of the APB in the Tempeh Kidul Village has been carried out quite well by the village government.
\end{abstract}

Keyword: Good Governance, Village Income and Expenditure Budget 


\section{PENDAHULUAN}

Penyelenggaraan pemerintahan desa diharapkan dapat mendorong peningkatan volume dan kemandirian melalui keikutsertaan masyarakat dalam memanfaatkan sumber daya untuk mencapai kesejahteraan masyarakat. Pelaksanaannya diwujudkan dalam bentuk sistem pemerintahan yang mengatur rencana pengembangan jangka panjang, kebijakan dan peraturan desa serta sumber pembiayaan pembangunan. Untuk mencapai tujuan yang diharapkan tersebut, pemerintah desa perlu memperhatikan implementasi tata kelola pemerintahan yang baik atau disebut dengan good governance.

Berdasarkan UNDP dalam Hidayatullah (2013:10), ada beberapa ciri-iri atau prinsip yang harus dianut dalam praktik penyelenggaraan pemerintahan yang baik, yaitu meliputi: partisipasi, aturan hukum, transparansi, daya tanggap, berorientasi konsensus, berkeadilan, efektivitas dan efisiensi, akuntabilitas serta visi yang strategis. Pada dasarnya untuk mewujudkan pemerintahan yang baik semua prinsip good governance harus dapat diimplementasikan secara maksimal dalam penyelenggaraan pemerintah desa. Persoalan yang terjadi adalah masih terdapat kekurangan dalam pengimplementasian prinsip-prinsip good governance.

Persoalan yang terjadi adalah penyelenggaraan pemerintahan desa masih banyak yang belum sesuai dengan prinsip-prinsip good governance atau pemerintahan yang baik. Salah satunya adalah unsur pertanggungjawaban atau akuntabilitas dan transparansi. Karena untuk dapat mewujudkan pemerintahan yang baik, hal yang harus diperhatikan adalah prinsip akuntabilitas, yaitu sebagai kewajiban dari individu atau penguasa yang dipercayakan untuk mengelola sumber-sumber daya publik dan yang bersangkutan dengannya untuk dapat menjawab hal-hal yang menyangkut pertanggungjawaban fiskal, manajerial, dan program.

Anggaran pendapatan dan belanja desa yang memadai juga dapat mendorong partisipasi warga lebih luas pada proses-proses perencanaan dan penganggaran pembangunan. Anggaran pendapatan dan belanja desa dapat menjawab partisipasi warga yang bersifat mikro dan mampu ditangani pada level desa. Proses penguatan pemerintahan desa (pemerintah desa dan badan permusyawaratan desa) perlu dilakukan dalam pengelolaan keuangan desa, khususnya tahap penyusunan, pelaksanaan dan pertanggungjawaban APB Desa, agar APB Desa yang disusun berorientasi kepada peningkatan kesejahteraan masyarakat desa dan memenuhi prinsip-prinsip good governance seperti transparansi, partisipasi, efektifitas dan akuntabilitas.

Prinsip good governance, diadaptasi dari Undang-Undang No.32 Tahun 2004 menjadi Asas-asas Umum Pemerintahan yang baik, terdiri atas: asas kepastian hukum, asas tertib penyelenggara negara, asas kepentingan umum, asas keterbukaan, asas proporsionalitas, asas protesionalitas, asas akuntabilitas, asas efisiensi dan asas elektivitas. Pengertian good governace yang terdapat pada pasal 2, RUU Administrasi Pemerintahan (Hukum Administrasi Negara), penyelenggaraan pemerintahan yang didasarkan pada hukum merupakan salah satu alternatif yang baik dalam penyelenggaraan negara. Berdasarkan pendapat diatas dapat disimpulkan bahwa good governance adalah penyelenggaraan pemerintah yang baik berdasarkan asas kepastian hukum, asas tertib penyelenggara negara, asas kepentingan umum, asas keterbukaan, asas proporsionalitas, asas protesionalitas, asas akuntabilitas, asas efisiensi dan asas elektivitas.

Akuntabilitas sebagai salah satu bentuk tanggung jawab pemerintah kepada masyarakat atas berbagai pengelolaan dan pelaksanaan pemerintahan di desa dirasakan kurang optimal, hal ini salah satunya terlihat pada kurang optimalnya tingkat pertanggungjawaban pengelola desa terhadap penyusunan anggaran pendapatan dan belanja desa di Tempeh Kidul, Kecamatan Tempeh, Kabupaten Lumajang. Selain itu, gejala permasalahan yang nampak yaitu kemampuan manejerial aparat desa dalam mengelola keuangan yang masih kurang, transparansi dalam pengelolaan keuangan desa belum sepenuhnya nampak terlihat, dan partisipasi atau keterlibatan masyarakat dalam proses mengawasi dan memberikan masukan yang afirmatif terhadap perbaikan 
pengelolaan keuangan desa belum sepenuhnya maksimal. Dari latar belakang tersebut peneliti tertarik untuk melakukan penelitian lebih mendalam.

Beberapa penelitian tentang implementasi good governance pada pengelolaan anggaran pendapatan dan belanja desa telah dilakukan oleh beberapa peneliti sebelumnya, diantaranya sebagai berikut: a. Rosielita (2017) hasil penelitian menunjukkan bahwa pengelolaan anggaran pendapatan dan belanja desa Telaga secara keseluruhan telah dilakukan sesuai dengan peraturan yang berlaku, namun pertanggungjawaban APB Desa kepada masyarakat hanya secara lisan melalui suatu forum diskusi yang diadakan oleh pemerintah desa Telaga dan prinsip-prinsip good governance pada pengelolaan anggaran pendapatan dan belanja desa Telaga sudah diterapkan cukup baik oleh pemerintah desa Telaga meskipun masih ada prinsip yang belum diterapkan secara optimal, yaitu prinsip transparansi dan akuntabilitas. b. Sari (2009) hasil penelitian menunjukkan bahwa APBD kabupaten Karanganyar tahun 2009 belum sepenuhnya menerapkan prinsip good governance yang pertama yaitu keterlambatan waktu proses penyusunan APBD tahun 2009. Kedua penerapan asas partisipatif pada proses penyusunan APBD tahun 2009 masih belum optimal karena hanya bersifat formalitas saja. Ketiga prinsip transparansi anggaran telah dilakukan namun masih perlu peningkatan lagi.

\section{METODE PENELITIAN}

Jenis penelitian ini adalah kualitatif. Penelitian ini dilakukan dengan pendekatan studi kasus. Penelitian kualitatif ini digunakan untuk menggambarkan implementasi good governance pada pengelolaan anggaran pendapatan dan belanja desa. Tempat penelitian ini dilaksanakan di kantor Balai Desa Tempeh Kidul kecamatan Tempeh kabupaten Lumajang. Jarak lokasi penelitian $12 \mathrm{~km}$ dari kampus STIE Widya Gama Lumajang. Pada penelitian ini sumber data diperoleh dari sumber internal yaitu dari Kantor Balai Desa Tempeh Kidul kecamatan Tempeh kabupaten Lumajang. Data yang dikumpulkan dan digunakan dalam penelitian ini adalah data primer dan sekunder. Data primer dalam penelitian ini diperoleh dari observasi dan wawancara dengan informan di obyek penelitian. Data sekunder dalam penelitian ini adalah dokumen-dokumen mengenai implementasi good governance pada pengelolaan anggaran pendapatan dan belanja desa di desa Tempeh Kidul kecamatan Tempeh kabupaten Lumajang berupa: a) Stuktur Organisasi Desa dengan Tugas dan Fungsi. b) Penetapan Rancangan APBDes. c) Rencana Pembangunan Jangka Menengah Desa (RPJMDesa). d) Rencana Kegiatan Pembangunan Desa (RKPDesa). Teknik analisis yang digunakan dalam penelitian ini yaitu analisis interaktif. Analisis interaktif meliputi empat komponen yaitu pengumpulan data, reduksi data, penyajian data, dan verifikasi data atau penarikan kesimpulan. Keempat kegiatan tersebut merupakan kegiatan yang jalin-menjalin pada saat sebelum, selama, dan sesudah pengumpulan data dalam bentuk yang sejajar untuk membangun wawasan umum yang disebut analisis.

\section{HASIL DAN PEMBAHASAN}

Keuangan Desa dikelola berdasarkan praktik-praktik pemerintahan yang baik. Asas-asas Pengelolan Keuangan Desa sebagaimana tertuang dalam UU Nomor 6 Tahun 2014 yaitu transparan, akuntabel, partisipatif serta dilakukan dengan tertib dan disiplin anggaran. Transparansi sebagai prinsip yang menjamin akses atau kebebasan bagi setiap orang untuk memperoleh informasi tentang penyelenggaraan pemerintahan, yakni informasi tentang kebijakan proses pembuatan dan pelaksanaanya serta hasil- hasil yang dicapai. Kemudahan memahami peraturan yang mengatur tentang tata cara pengelolaan keuangan termasuk APBDesa menjadi salah satu indikator transparansi pengelolaan APBDesa. Adanya mekanisme yang memfasilitasi pertanyaan-pertanyaan publik tentang proses-proses dalam penyelenggaraan pemerintahan memang dibutuhkan. 
Pemikiran masyarakat desa akan adanya kecurangan dalam penyelenggaraan pemerintahan memang tidak terlalu besar, karena kepedulian masyarakat desa akan hak dan kewajibannya dalam pengelolaan anggaran masih kurang. Oleh karena itu, pemerintah Desa Tempeh Kidul harus lebih mampu menunjukkan kepada masyarakat akan pentingnya partisipasi masyarakat dalam pengelolaan APB Desa secara transparan.

Pemerintah desa Tempeh Kidul telah mengupayakan keterbukaan informasi mengenai APBDesa dengan menampilkan di papan pengumuman balai desa atau dengan banner di halaman balai desa, dengan harapan setiap masyarakat yang datang ke balai desa bisa membaca langsung APBDesa Tempeh Kidul. Ibu Anita Kusuma Wardani, S.H. selaku Sekretaris Desa Tempeh Kidul mengatakan bahwa: "Informasi mengenai transparansi pengelolaan APBDesa tahun 2018 ini kami sampaikan di papan pengumuman atau melalui banner di halaman balai desa". Di papan pengumuman atau di banner tersebut kami sampaikan berapa dana desa yang diterima di tahun tersebut serta realisasi yang digunakan untuk apa saja. Itu kami sampaikan semua di papan pengumuman dan di banner termasuk rinciannya (wawancara, 15 Mei 2018). Berdasarkan hasil penelitian dan wawancara serta perbandingan dapat disimpulkan bahwa implementasi transpransi belum sepenuhnya dilaksanakan karena hanya diumumkan melalui papan pengumuman atau banner saja.

Akuntabilitas dalam penyelenggaraan pemerintahan dituntut disemua tahap mulai dari penyusunan program kegiatan, pembiayaan, pelaksanaan, dan evaluasinya, maupun hasil dan dampaknya. Untuk mengukur akuntabilits pemerintahan secara objektif perlu adanya standar dan indikator yang jelas untuk mengukur pelaksanaan penyelenggaraan pemerintahan, hasil pengukuran tersebut dipublikasikan serta ketika ada pelanggaran harus ada mekanisme pelaporan dan tindak lanjut terhadap pelanggaran yang terjadi. Mengenai laporan pertanggungjawaban dari pelaksanaan APBDesa, pemerintah desa setiap tahunnya memang harus mempertanggungjawabkan kinerja mereka. Laporan Pertanggungjawaban itu berisi tentang pendapatan desa, belanja desa dan pembiayaan desa. Hal ini sesuai dengan wawancara dengan Ibu Roshayati selaku bendahara desa Tempeh Kidul mengatakan bahwa "Setiap akhir periode saya membuat laporan pertanggungjawaban pelaksanaan APBDesa selama satu tahun anggaran. Laporan ini kemudian saya serahkan kepada kepala desa untuk ditindaklanjuti kepada camat. Laporan pertanggungjawaban pelaksanaan selanjutnya disampaikan kepada bupati melalui camat. Secara umum laporan pertanggungjawaban berisi jumlah pendapatan desa, pengeluaran atau belanja desa dan pembiayaan desa selama satu tahun anggaran." (Wawancara, 15 Mei 2018). Berdasarkan hasil penelitian dan wawancara penulis dapat simpulkan bahwa implementasi akuntabilitas di desa Tempeh Kidul sudah sesuai dengan prinsip-prinsip Good Governance dalam pengelolaan APBDesa.

Penerapan asas budaya hukum juga berlaku dalam pemerintahan desa. Apabila dalam pengelolaan APBDesa terjadi kelalaian, kecurangan maupun pelanggaran oleh suatu pihak, maka pemerintah desa dapat memberikan sanksi kepada pihak yang bersangkutan. Sanksi ini disesuaikan dengan seberapa besar kerugian yang ditimbulkan dan tergantung pada kebijakan pemerintah desa itu sendiri. Kepala Desa Tempeh Kidul, Bapak Drs. Mahrufin mengatakan bahwa "Pasti ada sanksi bagi mereka yang melanggar atau berbuat curang dalam pengelolaan APBDesa, kami akan menindak tegas setiap pelaku yang melakukan kecurangan”. Tapi itu semua ada tingkatan sanksinya, misalnya diukur dari seberepa besar kerugian yang ditimbulkan. Jika masih bisa ditoleransi, kami hanya berikan surat peringatan atau ganti rugi sejumlah rugi yang ditimbulkan. Namun sejauh ini belum ditemukan pelanggaran atau kecurangan dalam pengelolaan APBDesa di desa kami desa Tempeh Kidul ini, alhamdulillah lancar-lancar saja." (Wawancara, 15 Mei 2018). Berdasarkan uraian di atas maka dapat dinyatakan bahwa implementasi aturan hukum dalam pelaksanaan APBDesa di desa Tempeh Kidul telah dilakukan sesuai prinsip-prinsip good governance berdasarkan UNDP melalui LAN yang dikutip Tangkilis (2005:115). 
Pasal 23 ayat (1) UUD 1945 pasca perubahan ketiga tanggal 9 November 2001 telah memberikan landasan hukum yang kuat dalam rangka penerapan prinsip-prinsip good governance. Hal tersebut karena secara jelas diatur bahwa anggaran pendapatan dan belanja sebagai wujud dari pengelolaan keuangan ditetapkan setiap tahun dengan undang- undang dan dilaksanakan secara terbuka dan bertanggungjawab untuk sebesar- besarnya kemakmuran masyarakat.

Hasil wawancara dengan Kepala Desa Tempeh Kidul mengatakan bahwa: "Forum diskusi bersama BPD dan masyarakat yang kami adakan itu juga bertujuan untuk menampung aspirasi masyarakat desa, jadi tidak hanya terkait anggaran saja. Masyarakat bebas menyampaikan pendapatnya baik itu masukan untuk hal-hal yang berhubungan dengan pembangunan desa ataupun untuk kepentingan masyarakat itu sendiri. Semua pendapat dan masukan kami terima. Tapi dalam perwujudannya, tentu kami akan memprioritaskan hal-hal yang lebih penting." (Wawancara, 15 Mei 2018)

Partisipasi langsung masyarakat dalam pengelolaan APBDesa harus didorong oleh pemerintah desa sehingga terjadi keseimbangan peran antara masyarakat dan pemerintah desa. Masyarakat sebagai salah satu pelaku Good Governance harus berpartisipasi secara aktif dalam memberikan masukan dalam pengelolaan APBDesa dan meningkatkan pelayanan publik yang dilaksanakan pemerintah desa. Hal tersebut diakui oleh Bapak Saturi selaku Ketua BPD mengatakan bahwa "partisipasi masyarakat diperlukan dalam musyawarah desa karena prinsip APBDesa adalah pembangunan yang bersifat partisipatif. Masyarakat desa Tempeh Kidul cukup aktif menghadiri musyawarah desa”. (Wawancara, 15 Mei 2018)

Berdasarkan uraian di atas maka dapat dinyatakan bahwa implementasi partisipasi masyarakat dalam pelaksanaan APBDesa di desa Tempeh Kidul telah dilakukan sesuai prinsip-prinsip good governance berdasarkan UNDP melalui LAN yang dikutip Tangkilis (2005:115).

Awal dari tugas kepala desa terlantik yaitu diharuskan menyusun Rencana Pembangunan Jangka Menengah Desa (RPJMD) yang merupakan penjabaran dari visi dan misi dari calon kepala desa terpilih. Visi dan misi dari kepala desa yang terlantik berisi tentang bagaimana pembangunan yang harus dilakukan di desa Tempeh Kidul agar desa Tempeh Kidul lebih maju dalam segala hal baik dalam sarana prasarana, pendidikan, kesehatan maupun kesejahteraan masyarakatnya. Berdasarkan hal tersebut, kepala desa terlantik harus menyusun RPJMD sebagai awal dari penyusunan rancangan peraturan desa tentang APBDesa. Dalam UU Nomor 6 Tahun 2014 memiliki jangka waktu 5 (lima) tahun. Namun pada hasil wawancara dengan kepala desa, RPJMD di desa Tempeh Kidul memiliki jangka waktu selama masa jabatan kepala desa, ini merupakan perbedaan antara perencanaan pengelolaan keuangan sesuai UU Nomor 6 tahun 2014. Dalam wawancara dengan informan terjadi kesamaan pernyataan yang diungkapkan oleh masing-masing informan. Tetapi kenyataan di desa Tempeh Kidul RPJMDesa yang seharusnya berlaku 2013-2019 karena ada peraturan baru tahun 2014 maka ada perubahan menjadi berlaku 2015-2020. Menurut informan penetapan RPJMDesa lebih dari 3(tiga) bulan setelah kepala desa terlantik. Hal ini tidak sesuai dengan UU Nomor 6 Tahun 2014 bahwa penetapan RPJMDesa paling lambat 3 (tiga) bulan setelah kepala desa terlantik.

Penyusunan RKPDesa berdasarkan UU Nomor 6 Tahun 2014 dilakukan oleh kepala desa bersama BPD. Di desa Tempeh Kidul penyusunan RKPDesa melibatkan BPD dan semua lembaga kemasyarakatan desa. Musrenbangdes di desa Tempeh Kidul melibatkan seluruh komponen masyarakat yang meliputi Muspika, perangkat desa, BPD, LKMD, Tomas, Toga, Kepemudaan, PKK dan Gerbangmas. Selain itu terdapat kesamaan penetapan penyusunan RKPDesa di desa Tempeh Kidul. Di UU Nomor 6 Tahun 2014 penyusunan paling akhir bulan Januari, di desa Tempeh Kidul Musrenbangdes dilaksanakan pada bulan Januari.

Setelah penyusunan RKPDesa, maka selanjutnya penyusunan Rancangan Peraturan Desa tentang APBDesa. Berdasarkan UU Nomor 6 tahun 2014 langkah awal yaitu kepala desa membuat 
RPJMDesa (Rencana Pembangunan Jangka Menengah Desa) dan RKPDesa (Rencana Kerja Pembangunan Desa) yang disesuaikan dengan visi misi dan gagasan pembangunan yang harus dilakukan di desa Tempeh Kidul menjadi lebih maju dalam segala hal baik sarana prasarana fisik kesehatan, pendidikan dan kesejahteraan masyarakat. Dalam penyusunan RPJMDesa, pemerintah desa harus menyelenggarakan musyawarah perencanaan pembangunan desa (Musrenbangdes) secara partisipatif. RPJMDesa ditetapkan dalam jangka waktu paling lama 3(tiga) bulan terhitung sejak tanggal pelantikan kepala desa. Di desa Tempeh Kidul kepala desa yang sekarang mengikuti RPJMDesa yang penetapannya 2015 s.d. 2020. Dalam menyusun RPJMDesa disesuaikan dengan visi, misi dan berdasarkan pemikiran kepala desa untuk kemajuan desa. Pada saat penyusunan rencana kerja pembangunan desa (RKPDesa) yang disusun berdasarkan RPJMDesa, desa Tempeh Kidul mulai Musdes pada bulan awal Agustus dan penetapannya pada bulan September.

Sekretaris desa kemudian menyusun rancangan peraturan desa tentang APBDesa berdasarkan RKPDesa tadi. Rancangan peraturan desa tersebut kemudian akan diserahkan kepada kepala desa dan badan musyawarah desa untuk dibahas bersama guna mendapatkan persetujuan bersama. Dalam penentuan rancangan peraturan desa di desa Tempeh Kidul sudah sesuai waktunya dengan UU Nomor 6 Tahun 2014 dan berjalan dengan baik. Penetapan rancangan APBDesa Tempeh Kidul sudah sesuai dengan UU Nomor 6 Tahun 2014 yang berbunyi " Sekretaris desa menyusun rancangan peraturan desa tentang APBDesa berdasarkan RKPDesa tahun berkenan”. Hal ini sesuai dengan hasil wawancara dengan sekretaris desa pada tanggal 15 Mei 2018. Setelah sekretaris menyusun rancangan Perdes tentang APBDesa kemudian disampaikan kepada kepala desa. Hal ini sesuai dengan UU Nomor 6 Tahun 2014 yang berbunyi " Sekretaris desa menyampaikan rancangan peraturan desa tentang APBDesa kepada kepala desa. Hal ini sesuai dengan pernyataan kepala desa Bapak Drs. Makrufin pada saat wawancara dengan penulis pada tanggal 15 Mei 2018.

Rancangan APBDesa selanjutnya dibahas dengan Badan Permusyawaratan Desa (BPD) untuk disepakati bersama. Hal ini dilakukan berdasarkan UU Nomor 6 Tahun 2014 yang berbunyi "Rancangan peraturan desa tentang APBDesa sebagaimana dimaksud disampaikan oleh kepala desa kepada badan permusyawaratan desa untuk dibahas dan disepakati bersama". Hal ini sesuai penyataan Bapak Saturi selaku BPD desa Tempeh Kidul dalam wawancara pada tanggal 15 Mei 2017. Setelah melalui proses pembahasan antara kepala desa dengan BPD kemudian APBDesa dapat disepakati secara bersama tepatnya pada awal bulan Desember. Hal ini sesuai dengan hasil wawancara dengan kepala desa pada tanggal 15 Mei 2018.

Pernyataan kepala desa yang menyatakan bahwa "Setelah semua menyetujui dan menanggapi bahwa rancangan APBDesa telah selesai, sekretaris desa akan menyampaikan rancangan APBDesa itu kepada Bupati melalui Camat untuk dievaluasi, setelah itu baru peraturan tersebut disahkan menjadi peraturan desa.(wawancara 15 Mei 2018). Pernyataan tersebut juga menegaskan mengenai evaluasi rancangan peraturan desa tentang APBDesa tersebut akan disampaikan kepada camat. Tim evaluasi yang ditunjuk Bupati akan mengevaluasi rancangan tersebut dan akan menetapkan apakah rancangan peraturan desa tentang APBDesa tersebut disetujui atau tidak. Jika tidak maka kepala desa beserta BPD akan mengevaluasi kembali rancangan peraturan desa tentang APBDesa.

Kesepakatan antara kepala desa dan BPD desa Tempeh Kidul ini dilakukan berdasarkan UU Nomor 6 Tahun 2014 yang berbunyi "Rancangan peraturan desa tentang APBDesa disepakati bersama sebagaimana dimaksud paling lambat bulan Oktober tahun berjalan. Berdasarkan hasil penelitian dan wawancara serta perbandingan menunjukkan bahwa perencanaan APBDesa Tempeh Kidul tidak terdapat perbedaan dengan UU Nomor 6 Tahun 2014.

Berdasarkan hasil penelitian menunjukkan bahwa evaluasi rancangan APBDEsa Tempeh Kidul dengan UU Nomor 6 Tahun 2014 tidak terdapat perbedaan. Berdasarkan UU Nomor 6 Tahun 2014 bahwa evaluasi rancangan APBdesa yaitu Rancangan peraturan desa tentang APBDesa yang telah disepakati bersama sebagaimana dimaksud disampaikan oleh kepala desa kepada bupati/walikota 
melalui camat atau sebutan lain paling lambat 3 hari sejak disepakati untuk dievaluasi. Bupati/walikota menetapkan hasil evaluasi rancangan APBDesa sebagaimana dimaksud yaitu paling lama 20 hari kerja sejak diterimanya rancangan peraturan Desa tentang APBDesa. Dalam hal bupati/waikota tidak memberikan hasil evaluasi dalam batas waktu sebaimana dimaksud perdes tersebut berlaku dengan sendirinya. Dalam hal bupati/walikota menyatakan hasil evaluasi rancangan peraturan desa tentang APBDesa tidak sesuai dengan kepentingan umum dan peraturan perundang-undangan yang lebih tinggi, kepala desa melakukan penyempurnaan paling lama 7 hari kerja terhitung sejak diterimanya hasil evaluasi.

Di desa Tempeh Kidul hasil evaluasi rancangan APBDesa tahun 2017 telah dilakukan oleh Tim evaluasi kabupaten dengan hasil sebagai berikut: (1) hasil evaluasi terhadap rancangan peraturan desa Tempeh Kidul tentang anggaran pendapatan dan belanja desa tahun 2017. (2) Kepala Desa bersama BPD desa Tempeh Kidul harus melakukan penyempurnaan dan penyesuaian terhadap rancangan peraturan desa Tempeh Kidul tentang anggaran pendapatan dan belanja desa tahun anggaran 2017. Berdasarkan hasil evaluasi tersebut di atas paling lambat 7 hari terhitung sejak diterimanya hasil evaluasi (3) dalam hal kepala desa dan BPD tidak menindaklanjuti hasil evauasi dan tetap menetapkan rancangan peraturan desa tentang APBDesa tahun anggaran 2017 menjadi peraturan desa akan dilakukan pembatalan oleh Bupati, sekaligus menyatakan berlakunya pagu APBDesa tahun 2017. (4) keputusan ini mulai berlaku sejak tanggal ditetapkan.Berdasarkan hasil evaluasi dari Tim evaluasi kabupaten tersebut maka dapat disimpulkan bahwa rancangan APBDesa Tempeh Kidul perlu dilakukan penyempurnaan dan penyesuaian.

Setelah mendapat evaluasi dari tim evaluasi kabupaten kemudian kepala desa Tempeh Kidul menanggapinya. Adapun tanggapan atas evaluasi tim evaluasi kabupaten terhadap rancangan APBDesa Tempeh Kidul kecamatan Tempeh kabupaten Lumajang adalah sebagai berikut: Hasil evaluasi RAPBDesa tentang APBDesa sudah sesuai dengan UU Nomor 6 Tahun 2014 tentang pengelolaan keuangan desa dan permendagri No. 113 tahun 2015 tentang pedoman pembangunan desa. Penyempurnaan dan penyesuaian terhadap RAPBDesa sudah dilaksanakan. Kepala Desa Tempeh Kidul dan BPD sudah menindaklanjuti hasil evaluasi RAPBDesa yang sudah ditetapkan oleh Tim Evaluasi Kabupaten tentang penetapan besaran dana desa tahun anggaran 2018. Peraturan Kepala Desa Tempeh Kidul tentang APBDesa ditetapkan dan diundangkan setelah tanggapan hasil evaluasi Tim evaluasi kabupaten ditetapkan. Berdasarkan uraian di atas maka dapat dinyatakan evaluasi APBDesa Tempeh Kidul telah dilakukan sesuai UU Nomor 6 Tahun 2014 sehingga dapat dinyatakan bahwa kegiatan evaluasi APBDesa Tempeh Kidul telah sesuai dengan evaluasi UU Nomor 6 Tahun 2014 dan dapat dijadikan peraturan desa.

Berdasarkan UU Nomor 6 Tahun 2014 bahwa pelaksanaan pengelolaan keuangan desa berbunyi pelaksana kegiatan mengajukan pendanaan untuk melaksanakan kegiatan harus disertai dengan dokumen antara lain Rencana Anggaran Biaya (RAB). Ayat (2) berbunyi RAB sebagaimana dimaksud pada ayat 1 diverifikasi oleh sekretaris desa dan disyahkan oleh kepala desa. Ayat (3) berbunyi pelaksana kegiatan bertanggung jawab terhadap tindakan pengeluaran yang menyebabkan atas beban anggaran belanja kegiatan dengan mempergunakan buku pembantu kas kegiatan sebagai pertanggungjawaban pelaksanaan kegiatan di desa.

Pelaksanaan keuangan desa Tempeh Kidul secara keseluruhan terlaksana dengan baik. Bahkan bisa dikatakan sangat disiplin. Dimulai dari perencanaan Rincian Anggaran Pendapatan Desa (RAPBDesa) dan disusunnya Rencana Anggaran Biaya (RAB) selanjutnya baru menjadi peraturan desa. Dalam setiap kegiatan pelaksanaan di desa Tempeh Kidul sudah dijalankan dengan baik, sistem pelaksanaan kegiatan di desa Tempeh Kidul sudah sesuai dan berpedoman pada RAB yang telah disusun. Semua kegiatan sudah dijalankan sesuai rencana yang telah dianggarkan sebelumnya dengan periode yang telah ditetapkan. Apabila ada perubahan kegiatan dalam tahun berkenaan bisa dilakukan melalui pembuatan perdes PAK APBDesa yang diputuskan melalui musyawarah desa. 
Berdasarkan uraian di atas maka dapat dinyatakan bahwa pelaksanaan keuangan di desa Tempeh Kidul telah dilakukan sesuai UU Nomor 6 Tahun 2014 sehingga dapat dinyatakan bahwa pelaksanaan pengelolaan keuangan desa Tempeh Kidul telah sesuai dengan pelaksanaan pengelolaan UU Nomor 6 Tahun 2014.

\section{KESIMPULAN}

Berdasarkan hasil kegiatan penelitian dan pembahasan yang telah dijelaskan sebelumnya, maka dapat disimpulkan sebagai berikut bahwa perencanaan APBDesa Tempeh Kidul dalam perencanaan pengelolaan keuangan desa cukup baik. Pelaksanaan keuangan desa Tempeh Kidul secara keseluruhan terlaksana dengan baik. Implementasi prinsip-prinsip good governance pada pengelolaan APBDesa Tempeh Kidul sudah dilaksanakan cukup baik oleh pemerintah desa. Saran bagi Pemerintah Kabupaten Lumajang khususnya DPM kabupaten Lumajang agar selalu memberikan bimbingan kepada petugas desa yang belum maksimal dalam merencanakan dan melaksanakan keuangan desa, tidak terlalu sering mengubah peraturan mengenai pedoman pengelolaan keuangan desa yang menimbulkan kebingungan bagi pelaksananya, dalam memberikan juknis harus jelas dan memberikan tenaga ahli dalam bidang perencanaan, pengelolaan dan pelaksanaan keuangan desa kepada desa-desa yang tidak memiliki tenaga ahli untuk bidang tersebut jika sangat diperlukan. Bagi pihak Inspektorat kabupaten Lumajang diharapkan lebih jeli dan teliti dalam mengecek laporan keuangan desa, dan memberikan saran yang bermakna bagi pemerintah desa itu sendiri. Bagi pihak pemerintah kecamatan Tempeh agar sering melakukan pembinaan kegiatan desa khususnya yang berkenaan dengan pengelolan keuangan yang disesuaikan dengan UU Nomor 6 Tahun 2014 supaya tidak terjadi penyelewengan wewenang bahkan penyelewengan anggaran.

\section{UCAPAN TERIMA KASIH}

Puji syukur kehadirat Tuhan YME dengan terselesainya penelitian ini, terima kasih kepada dr. Niswah Nilam Qanitah sebagai Kepala Puskesmas Leces dan staf Puskesmas Leces yang telah membantu dan memberikan kesempatan penelitian, terima kasih kepada Ibu Indah dan Ibu Susi sebagai koordinator survey dan petugas pembantu lapangan, terima kasih juga kepada semua pihak yang tidak disebutkan disini yang membantu dan ikut andil dalam kelancaran penelitian ini.

\section{DAFTAR PUSTAKA}

Azwar,Saifuddin. (2011). Metode Penelitian. Pustaka Pelajar. Yogyakarta.

Gunawan, Iman. (2014). Metode Penelitian Kualitatif Teori dan Praktik. Jakarta: PT Bumi Aksara. Herdiansyah, Haris. (2009). Metodologi Penelitian Kualitatif untuk Ilmu-Ilmu Sosial.

Peraturan Daerah Nomor 20 Tahun 2006 Tentang Desa

Peraturan Pemerintah RI No. 24 Tahun 2005 tentang Standar Akuntansi Pemerintah.

Peraturan Menteri Dalam Negeri Nomor 13 tahun 2006 Tentang Pedoman Pengelolaan Keuangan Daerah.

Peraturan Menteri Dalam Negeri Nomor 113 tahun 2014 tentang Pedoman Pengelolaan Keuangan Desa.

Peraturan Bupati Kabupaten Lumajang No. 37 tahun 2016 tentang Struktur Organisasi Pemerintah Desa.

Peraturan Bupati Lumajang Nomor 7 Tahun 2017 tentang Alokasi Dana Desa.

Rosielita, Febi. (2017). Implementasi Good Governance pada Pengelolaan Anggaran Pendapatan dan Belanja Desa (Studi Kasus pada Desa Telaga Kecamatan Busungbiu Kabupaten Buleleng). e-Journal S1 Ak (Vol: 8 No: 2 Tahun 2017) Universitas Pendidikan Ganesa.

Sari, Karmila. (2009). Implementasi Prinsip Good Governance dalam Proses Penyusunan APBD Tahun 2009 di Kabupaten Karanganyar. Skripsi tidak diterbitkan. Fakultas Hukum Universitas Negeri Surakarta.

UU RI Nomor 6 Tahun 2014 tentang Desa. 
UU RI Nomor 32 Tahun 2004 tentang Desa. 